\title{
Proporsi peresepan probiotik pada gastroenteritis akut pasien pediatri di bangsal rawat inap RS X pada Februari 2015
}

\author{
Dita Maria Virginia \\ Fakultas Farmasi, Universitas Sanata Dharma \\ Kampus III Paingan, Maguwoharjo, Depok, Sleman, DI Yogyakarta
}

Submitted: 29-04-2016

Reviewed: 17-10-2016

Accepted: 03-11-2016

\begin{abstract}
ABSTRAK
Pasien anak (pediatri) merupakan salah satu kelompok sasaran Sistem Kesehatan Nasional Indonesia tahun 2009 yang memerlukan perhatian khusus dalam pemberian terapi karena anatomi fisiologi yang immature. Probiotik banyak diindikasikan untuk pasien dengan diagnosa gastroenteritis akut (GEA). Pemberian probiotik meliputi jenis probiotik, dosis, dan durasi untuk GEA belum terlihat jelas. Penelitian ini secara umum bertujuan untuk melihat perbedaan proporsi peresepan probiotik (jenis, dosis, dan durasi) dengan indikasi GEA terhadap usia pasien di bangsal rawat inap. Penelitian ini merupakan penelitian observasional analitik dengan rancangan cross sectional dan data diperoleh secara retrospektif. Pengambilan sampel secara non purposive sampling dan besar sampel berdasarkan rancangan cross sectional dan diperoleh sejumlah 200 rekam medis dari RS X, Indonesia pada Februari 2015. Penelitian ini menggunakan data sekunder berupa rekam medis. Data yang diambil meliputi identitas pasien, umur, peresepan probiotik yaitu jenis spesies, dosis, dan durasi. Data dianalisis secara deskriptif dan Mann-Whitney untuk melihat perbedaan jenis spesies, dosis, dan durasi penggunaan probiotik terhadap usia. Hasil penelitian menunjukkan di rumah sakit ini menggunakan 5 merk probiotik. Pemilihan jenis probiotik pada usia $<2$ tahun lebih banyak menggunakan 3 jenis sedangkan pada usia $\geq 2$ tahun memilih 6 jenis. Rerata penggunaan dosis lebih besar pada kelompok usia $\geq 2$ tahun. Durasi penggunaan probiotik pada kelompok $<2$ tahun lebih banyak pada penggunaan selama 4 hari sedangkan pada usia $\geq 2$ tahun pada durasi 5 hari. Jumlah kasus yang tidak sesuai dosis anjuran kemasan lebih banyak pada usia $<2$ tahun. Terdapat perbedaan proporsi yang bermakna secara statistik antara jenis probiotik $(\mathrm{p}=0,000)$, dosis $(\mathrm{p}=0,040)$, dan durasi $(\mathrm{p}=0,008)$ terhadap kelompok usia pediatri $<2$ tahun dan $\geq 2$ tahun. Terdapat perbedaan proporsi yang bermakna secara statistik antara peresepan probiotik (jenis spesies probiotik, dosis, dan durasi) untuk GEA terhadap kelompok usia pediatri $<2$ tahun dan $\geq 2$ tahun.
\end{abstract}

Kata kunci: probiotik, pediatri, gastroenteritis akut

\begin{abstract}
Pediatric patients are one of the target groups of the National Health System in Indonesia that requires special attention in therapy because their anatomy physiology was immature. A lot of probiotics indicated for acute gastroenteritis (AGE) for pediatric patients. Probiotic prescribing includes the types of probiotic, dosage and duration for AGE has not been discussed clearly. The aim of our study was to determine the proportion of probiotic that have prescribed for acute gastroenteritis to pediatric aged in hospitalized. This study was analytical observational with cross sectional design. Data was obtained retrospectively with non-purposive sampling. Sample size was based on cross-sectional design calculation and obtained a number of 200 medical records from Hospital X, Indonesia on February 2015. This study used secondary data from medical records. Data collected was patient identity, patient aged, probiotic prescribing includes the types of probiotic, dosage and duration. Data have been analyzed in descriptive and Mann-Whitney to observe the difference between types of probiotic, dosage and duration probiotic used to pediatric aged.
\end{abstract}

Penulis korespondesi:

Dita Maria Virginia

Fakultas Farmasi, Universitas Sanata Dharma

Kampus III Paingan, Maguwoharjo, Depok, Sleman, Yogyakarta

Email: virginia@usd.ac.id 
This study showed this hospital only used 5 probiotic brands. Group aged $<2$ years is more used of 3 types of probiotic species while at the age of $>2$ years is prefer to use 6 types. The mean dose of probiotic is greater in the group aged $\geq 2$ years. Probiotic duration in the group $<2$ years is for 4 days while in those aged $\geq 2$ years in duration 5 days. The number of cases that do not fit with the recommended dose packs is more commonly found at age $<2$ years. There is a different proportion between type of probiotic $(\mathrm{p}=0.000)$, dose of probiotic $(\mathrm{p}=0.040)$, and probiotic duration $(\mathrm{p}=0.008)$ with pediatric aged. There was a statistically significant difference between types of probiotic, dosage and duration probiotic used to pediatric aged.

Keywords: probiotic, pediatric, acute gastroenteritis

\section{PENDAHULUAN}

Gastroenteritis akut (GEA) merupakan kondisi yang prevalensinya tinggi pada populasi pediatri di negara berkembang dan umumnya disebabkan karena virus (rotavirus, norovirus, dan adenovirus) ataupun bakteri pathogen (Fletcher et al., 2013). Hasil riset kesehatan daerah 2013 menunjukkan prevalensi diare pada balita, sebagai salah satu kondisi GEA, di Indonesia sebesar 5\% dan di D.I Yogayakarta sebesar 3,8\% (Kementerian Kesehatan RI, 2013).

Terapi probiotik diperlukan pada pasien pediatri dengan kondisi GEA (Szajewska et al., 2014). Penelitian meta-analisis menunjukkan terapi Lactobacillus untuk GEA pada pasien rawat inap mampu mengurangi kejadian diare 0,7 hari dan mengurangi frekuensi diare 1,6 pada hari kedua terapi (Van Niel et al., 2002). Probiotik merupakan suplemen yang nondigestible dan mengandung mikroorganisme hidup yang secara natural dan alami hidup di dalam tubuh manusia (flora normal). Probiotik berfungsi untuk menstimulasi pertubuhan dam stimulasi aktivitas flora normal. Food and Drug Administration (FDA) masih belum memberikan klaim terkait manfaat kesehatan dari konsumsi probiotik (Bonifait et al., 2009; Thomas dan Greer, 2010).

Data National Health Interview Survey pada tahun 2007 di Amerika menunjukkan bahwa penggunaan probiotik menempati urutan kelima produk yang paling banyak digunakan oleh populasi pediatri tapi tidak di populasi dewasa. Konsumsi produk probiotik bahkan lebih banyak pada area Eropa dan Jepang (Vanderhoof, 2008). Prevalensi konsumsi produk probiotik di Indonesia belum terdeteksi jelas, namun beberapa penelitian mengenai probiotik sudah mulai terpublikasi pada awal tahun 2009 . Penelitian penggunaan probiotik selama ini lebih berfokus pada penggunaannya pada pasien diare (Menkes, 2009; Korompis et al., 2013).

Pediatri merupakan salah satu kelompok sasaran Sistem Kesehatan Nasional (SKN) 2009 dan termasuk di dalam salah satu kelompok rentan. Pediatri rentan menderita penyakit karena sistem imun dan fungsi fisiologi organ belum berkembang sempurna, selain itu pediatri merupakan tahap tumbuh kembang terhadap lingkungan dan aktivitas bermain dengan lingkungan sekitar yang tidak terjamin higienisitasnya. Penelitian Thiem et al., (2012) di Vietnam mendukung pernyataan tersebut dengan hasil bahwa anak di bawah umur 5 tahun rentan menjalani rawat inap dengan diagnosa diare sebgai manifestasi klinis GEA karena sanitasi dan higienisitas personal yang buruk. Pediatri seringkali menjalani rawat inap karena mengalami penyakit infeksi ringan seperti diare, infeksi berat seperti TBC. Penggunaan probiotik pada pasien pediatri sebagai terapi kondisi patologis masih memerlukan banyak penelitian terutama terkait dengan efek jangka panjang penggunaan probiotik (Thomas et al., 2010).

Penelitian Korompis et al., (2013) di Indonesia mengenai studi penggunaan obat pada pasien diare menunjukkan bahwa pasien menerima probiotik sebanyak 12\%. Penelitian Menkes (2009) pada pasien pediatri yang mengalami rawat inap karena diare menunjukkan bahwa penggunaan probiotik dapat meningkatkan proses perbaikan intestinal sehingga mengurangi keparahan diare karena GEA. Data pada penelitian ini dapat berguna untuk melihat proporsi peresepan probiotik terkait dengan jenis, dosis, dan durasi penggunaan pada pasien GEA.

Pada penelitian ini lebih berfokus pada penggunaan probiotik yang diresepkan bukan penggunaan sehari-hari karena ingin melihat secara jelas gambaran penggunaan probiotik terkait jenis, dosis, dan durasi pemakaian. Penelitian ini juga lebih berfokus pada pasien rawat inap karena penggunaan probiotik dalam peresepan di rawat inap dapat terdeteksi lebih akurat dan jelas daripada penggunaan selama rawat jalan.

Pharmaciana Vol. 6, No. 2, November 2016, Hal. 149-154 
Penelitian ini merupakan penelitian observasional analitik dengan rancangan cross sectional. Pengambilan data dilakukan secara retrospektif dengan melakukan pengambilan data melalui rekam medis. Variabel dalam penelitian ini meliputi usia subjek dan peresepan probiotik (jenis spesies, dosis, dan durasi penggunaan). Usia pada penelitian ini dibatasi usia 0 sampai dengan 12 tahun. Jenis probiotik merupakan komposisi probiotik di tiap sediaan dihitung berapa jumlah spesies yang terkandung di dalamnya, dosis dihitung dari jumlah probiotik yang diminum tiap kali minum (dinyatakan dalam jumlah CFU probiotik secara keseluruhan), dan durasi dihitung dari saat pasien menerima probiotik sampai dengan probiotik terakhir diperoleh. Apabila terdapat peresepan probiotik yang diresepkan untuk dibawa pulang maka disesuaikan dengan jumlahnya. Usia akan dikelompokkan menjadi dua yaitu $<2$ tahun dan $\geq 2$ tahun karena ada perbedaan parameter farmakokinetik di kedua kelompok usia tersebut (Lu et al., 2014).

\section{Subjek dan Lokasi Penelitian}

Subjek penelitian ini adalah semua pasien anak di bangsal perawatan yang menjalani rawat inap dengan diagnosa gastroenteritis akut (GEA), dengan kode ICD10 A08 atau A09, dan memperoleh terapi probiotik pada saat bulan Februari 2015. Pengambilan sampel secara non-purposive sampling dan besar sampel diambil menggunakan rumus sampel pada studi cross sectional dengan proporsi sebesar 0,5 taraf kepercayaan $95 \%$ dan kekuatan $80 \%$, yaitu didapatkan jumlah sampel rekam medis yang harus diambil sebesar 196 dan akan dibulatkan menjadi 200. Bahan penelitian ini adalah rekam medis dan formulir untuk mencatat data pasien.

\section{Jalannya Penelitian}

Penelitian dilakukan dengan mengambil kasus dari pasien yang telah menjalani perawatan di Instalasi Anak di RS X Yogyakarta pada Februari 2015. Penelitian dimulai dengan studi pendahuluan dan proses perijinan di rumah sakit. Penelitian dilakukan dengan mengumpulkan data sekunder dari catatan rekam medis pasien di RS X Yogyakarta, selanjutnya data akan dicatat dalam formulir penelitian. Beberapa parameter yang diambil meliputi: 1). data diri pasien (umur, alamat, dan nomor rekam medis), 2). informasi obat (dosis, sediaan, jumlah, dan cara pemberian), dan 3). diagnosa penyakit. Data sekunder yang diperoleh serta memenuhi kriteria inklusi dikumpulkan dan dicatat dalam kertas formulir. Data akan dipindahkan ke Microsoft Excel ${ }^{\circledR}$. Peneliti tidak menyebutkan secara jelas mengenai identitas pasien yang tercatat pada rekam medis pada saat penelitian, analisis data, maupun publikasi sehingga kondisi medis responden tetap terjaga.

\section{Analisis Data}

Data secara deskriptif menampilkan distribusi penggunaan probiotik dan membandingkan kesesuaian dosis probiotik antara yang diresepkan dengan dosis pada kemasan. Dosis pada kemasan digunakan sebagai standar karena belum ada guideline dosis probiotik. Analisis data analitik melihat perbedaan proporsi probiotik (jenis spesies probiotik, dosis, dan durasi) pada kedua kelompok umur $(<2$ tahun dan $\geq 2$ tahun). Normalitas data dilihat dengan Kolmogorov Smirnov ( $p>0,05)$ dan diperoleh data tidak terdistribusi normal. Uji statistik untuk melihat perbedaan jenis spesies, dosis, dan durasi penggunaan probiotik terhadap usia menggunakan Mann-Whitney.

\section{HASIL DAN PEMBAHASAN}

Penggunaan probiotik telah terbukti efektif mengatasi GEA pada pasien pediatri. Salah satu fungsi probiotik adalah meningkatkan aktivitas imunomodulasi pada saliva dan menurunkan jumlah mutasi dari Streptococcus sp. Probiotik strain Lactobacillus dan Bifidobacterium juga terbukti mengatasi GEA dengan mengurangi jumlah bakteri enterovirulen (Wattanarat et al., 2014; Moal dan Servin, 2014; Varankovich et al., 2015).

Data keseluruhan pada penelitian ini berjumlah 200 kasus GEA yang menggunakan probiotik dan diperoleh dari 200 rekam medis. Pada Tabel I menunjukkan jenis kelamin perempuan memiliki proporsi lebih besar. Pemilihan jenis probiotik pada usia $<2$ tahun lebih banyak menggunakan 3 jenis spesies sedangkan pada usia $\geq 2$ tahun memilih 6 jenis spesies. Rerata penggunaan dosis pada kelompok usia $\geq 2$ tahun lebih tinggi daripada kelompok $<2$ tahun. Durasi penggunaan probiotik pada kelompok $<2$ tahun lebih banyak pada penggunaan selama 4 hari sedangkan pada usia $\geq 2$ tahun pada durasi 5 hari. 
Penggunaan probiotik untuk diagnosa GEA di rumah sakit ini hanya ada 5 jenis merk yaitu Liprolac ${ }^{\circledR}$, Lacbon $^{\circledR}$, Lacidofil ${ }^{\circledR}$, Lacto $\mathrm{B}^{\circledR}$, dan L-Bio ${ }^{\circledR}$. Pada Gambar 1 terlihat bahwa lacto $\mathrm{B}^{\circledR}$ memiliki porsi terbesar sebagai pilihan terapi probiotik. Lacto $\mathrm{B}^{\circledR}$ merupakan salah satu merk probiotik dengan kandungan 3 jenis spesies probiotik.

Tabel I. Karakteristik subyek penelitian

\begin{tabular}{|c|c|c|c|}
\hline Karakteristik & $\begin{array}{c}<2 \text { tahun }(\mathrm{n}=119) \\
\text { n }(\%)\end{array}$ & $\begin{array}{c}\geq 2 \text { tahun }(n=81) \\
n(\%)\end{array}$ & $\begin{array}{c}\text { Total }(n=200) \\
n(\%)\end{array}$ \\
\hline \multicolumn{4}{|l|}{ Jenis kelamin } \\
\hline -laki-laki & $57(47,9)$ & $31(38,3)$ & $88(44,0)$ \\
\hline -perempuan & $62(52,1)$ & $50(61,7)$ & $112(56,0)$ \\
\hline \multicolumn{4}{|l|}{ Jenis spesies probiotik } \\
\hline - 1 spesies & $37(31,1)$ & $8(9,9)$ & $45(22,5)$ \\
\hline - 3 spesies & $54(45,4)$ & $21(26)$ & $75(37,5)$ \\
\hline - 6 spesies & $10(8,4)$ & $41(50,6)$ & $51(25,5)$ \\
\hline - 7 spesies & $18(15,1)$ & $11(13,6)$ & $29(14,5$ \\
\hline Dosis probiotik $\left(10^{8} \mathrm{CFU}\right)^{*}$ & $14,3 \pm 11,1$ & $16,7 \pm 10,2$ & $15,03+11,08$ \\
\hline \multicolumn{4}{|l|}{ Durasi probiotik } \\
\hline-2 hari & $23(19,3)$ & $17(21,0)$ & $40(20,0)$ \\
\hline - 3 hari & $29(24,4)$ & $8(9,9)$ & $37(18,5)$ \\
\hline - 4 hari & $46(38,7)$ & $20(24,7)$ & $66(33,3)$ \\
\hline-5 hari & $13(10,9)$ & $22(27,2)$ & $35(17,5)$ \\
\hline-6 hari & $8(6,7)$ & $13(16,0)$ & $21(10,5)$ \\
\hline-8 hari & $0(0)$ & $1(1,2)$ & $1(0,5)$ \\
\hline
\end{tabular}

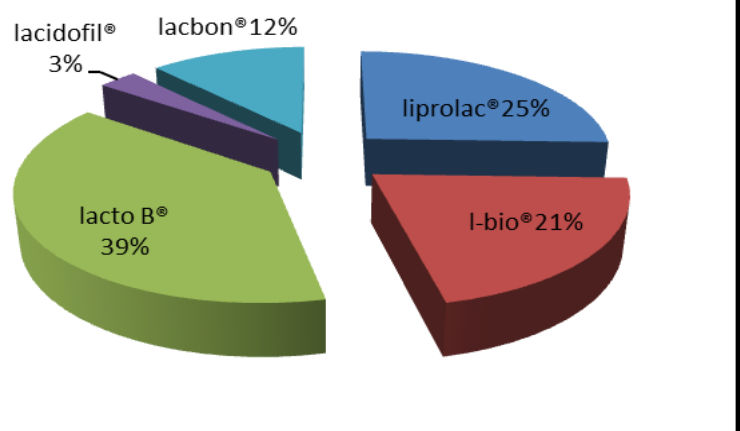

Gambar 1. Distribusi penggunaan probiotik

Pada Tabel II terlihat perbedaan antara kelompok usia $<2$ tahun dan $\geq 2$ tahun dalam peresepan probiotik. Hasil analisis menggunakan Mann-Whitney menunjukkan adanya perbedaan proporsi yang bermakna secara statistik antara jumlah jenis spesies probiotik $(\mathrm{p}=0,008)$, dosis $(\mathrm{p}=0,040)$, dan durasi $(\mathrm{p}=0,000)$ terhadap kelompok usia pediatri $<2$ tahun dan $\geq 2$ tahun. Tinjuan dari segi jenis spesies, dosis, dan durasi penggunaan probiotik menunjukkan kelompok usia $\geq 2$ tahun memiliki nilia rerata lebih tinggi dibandingkan kelompok usia $<2$ tahun. Adanya perbedaan bermakna penggunaan probiotik perlu adanya penelitian lebih lanjut terkait efek yang ditimbulkan pada kedua kelompok umur tersebut. Hal ini didasari pula dengan kurangnya guideline baik nasional ataupun internasional terkait penggunaan probiotik pada kelompok pediatrik.

Penelitian (Boyle et al., 2006) menemukan bahwa probiotik aman digunakan pada orang sehat namun perlu ada perhatian khusus pada beberapa kasus karena dapat meningkatkan risiko sepsis. Beberapa strain spesies probiotik juga memerlukan penelitian lebih lanjut karena adanya perbedaan strain/spesies dapat menimbulkan efek yang berbeda pula. Pada penelitian ini terdapat perbedaan bermakna jenis spesies pada kedua kelompok umur. Perlu diperhatikan pula bahwa kelompok $<2$ tahun memiliki persentase lebih besar memperoleh probiotik yang mengandung 7 jenis spesies dibandingkan usia $\geq 2$ tahun. 
Penelitian meta analisis (Ahmadi et al., 2015) menunjukkan bahwa dosis berkorelasi terhadap berkurangnya durasi diare akut, namun tetap menyebutkan perlu adanya penelitian lebih lanjut yang spesifik terkait dosis. Pada penelitian ini terlihat ada perbedaan bermakna. Secara teoritis, hal ini sesuai karena kelompok usia $>2$ tahun merupakan awal perbaikan organ ekskresi dengan fungsi renal yang sama dengan fungsi dewasa sehingga memiliki kemampuan eliminasi lebih baik daripada kelompok $<2$ tahun (Lu et al., 2014). Hubungan lama penggunaan probiotik terhadap usia juga belum diteliti sehingga hal ini membutuhkan penelitian lebih lanjut. Ketidaksesuian dosis probiotik berisiko meningkatkan aktivitas respon imun non spesifik. Pengkajian terkait penggunaan probiotik perlu mempertimbangkan hubungan antara efektivitas strain probiotik terhadap kondisi pasien, status fisiologi pasien dimana pasien pediatri infants dan pasien kritis membutuhkan penanganan khusus, hindari penggunaan bersama probiotik, dan pastikan ketepatan dosis (Sanders et al., 2010).

Tabel II. Perbedaan peresepan probiotik terhadap usia pasien

\begin{tabular}{|c|c|c|c|}
\hline \multirow[t]{2}{*}{ Karakteristik } & \multicolumn{2}{|c|}{ n $(\%)$} & \multirow[t]{2}{*}{$\mathbf{p}$} \\
\hline & $\begin{array}{c}<2 \text { tahun } \\
n=119\end{array}$ & $\underset{n=81}{2 \text { tahun }}$ & \\
\hline Jenis spesies probiotik & $3,2+2,1$ & $4,9+1,9$ & 0,000 \\
\hline Dosis probiotik $\left(10^{8} \mathrm{CFU}\right)$ & $14,3 \pm 11,1$ & $16,7 \pm 10,2$ & 0,040 \\
\hline Durasi (hari) & $3,6+1,1$ & $4,1+1,4$ & 0,008 \\
\hline
\end{tabular}

Administrasi strain probiotik yang efektif mampu mengurangi durasi lama tinggal di rumah sakit dan dapat menjadi bahan pertimbangan terapi pada pasien pediatri dengan GEA. Probiotik mampu mengurangi gejala AGE dan Lactobacillus sp., L. rhamnosus $G G$ dan atau $S$ boulardii atau Bifidobacterium sp. merupakan strain probiotik yang paling direkomendasikan (Freedman et al., 2015; Varankovich et al., 2015). Probiotik pada penelitian yang digunakan di rumah sakit lokasi penelitian seluruhnya menggunakan produk probiotik yang mengandung Lactobacillus sp., L. rhamnosus $G G$ dan atau $S$ boulardii atau Bifidobacterium sp. Tidak ada penelitian yang serupa dengan penelitian ini terkait dengan melihat perbedaan proporsi pada 2 kelompok usia pediatri sehingga tidak ada jurnal pembanding. Beberapa penelitian mengungkapkan terapi GEA juga membutuhkan oral rehidrasi selain probiotik (Ciccarelli et al., 2013).

Keterbatasan penelitian ini adalah tidak adanya pengamatan terkait efektivitas terapi probiotik terhadap status GEA. Penelitian ini hanya mengkaji ada tidaknya perbedaan penggunaan antar dua kelompok usia. Perlu penelitian lebih lanjut untuk melihat efektivitas penggunaan probiotik terhadap lama hari perawatan pasien dengan diagnose GEA untuk mengobservasi efektivitas terapi.

\section{KESIMPULAN}

Terdapat perbedaan proporsi yang bermakna secara statistik antara peresepan probiotik (jenis spesies probiotik, dosis, dan durasi) untuk GEA terhadap kelompok usia pediatri $<2$ tahun dan $\geq 2$ tahun. Penelitian selanjutnya perlu melihat hubungan penggunaan probiotik terhadap lamanya hari perawatan serta kesesuaian dosis berdasarkan spesies probiotik.

\section{UCAPAN TERIMAKASIH}

Terimakasih kepada bantuan penelitian oleh Lembaga Penelitian dan Pengabdian Masyarakat (LPPM) Universitas Sanata Dharma dan Dr.Rita Suhadi, Apt. atas diskusi dalam proses penyusunan artikel ini.

\section{DAFTAR PUSTAKA}

Ahmadi, E., Alizadeh-Navaei, R., and Rezai, M.S., 2015, Efficacy of probiotic use in acute rotavirus diarrhea in children: a systematic review and meta-analysis, Caspian J Intern Med, 6(4):187-195.

Bonifait L, Chandad F, Grenier D., 2009, Probiotics for oral health: myth or reality?, Journal (Canadian Dental Association), 75(8) : 585-590.

Boyle, R.J., Robins-browne, R.M. \& Tang, M.L.K., 2006, Probiotic use in clinical practice : what are the risks ?, Am J Clin Nutr, 83 : 1256 - 64.

Ciccarelli, S., Stolfi, I., Caramia, G., 2013, Management strategies in the treatment of neonatal and pediatric gastroenteritis, Infection and Drug Resistance, 6: 133-161. 
Connecticut Hospital Association, 2014, Pediatric Hospitalization, http://www.chime.org/advocacy/quality-and-patient-safety/patients-guide-to-quality-hospitalcare/pediatric-hospitalization/, diakses tanggal 22 April 2014.

Fletcher, S.M., McLaws, M., and Ellis, J.T., 2013, Prevalence of gastrointestinal pathogens in developed and developing countries: systematic review and meta-analysis, J Public Health Res., Apr 28; 2(1): 42-53.

Freedman, A.B., Pasichnyk, D., Black, K.J.L., Fitzpatrick, E., Gouin, S., et al., 2015, Gastroenteritis therapies in developed countries: systematic revies and meta-analysis, Plos One.

Lu, H., Rosenbaum, S. and Island, R., 2014, Developmental pharmacokinetics in pediatric populations, $J$ Pediatr Pharmacol Ther, 19(4):262-276.

Kementerian Kesehatan RI, 2013, Riset Kesehatan Dasar 2013, Badan Penelitian dan Pengembangan Kesehatan Kementerian Kesehatan, 73.

Korompis, F., Tjitrosantoso, H., dan Goenawi, L.R., 2013, Studi penggunaan obat pada penderita diare akut di instalasi rawat inap blu RSUP Prof. Dr. R. D. Kandou Manado Periode Januari - Juni 2012, Jurnal Ilmiah Farmasi - UNSRAT, 2(1): 42-52.

Menteri Kesehatan, 2009, Sistem Kesehatan Nasional. Departemen Kesehatan RI, 4.

Moal, V.L., and Servin, A.L., 2014, Anti-infective activities of Lactobacillus strains in the human instestinal microbiota: from probiotics to gastrointestinal anti-infectious biotherapuetic agents, Clinical Microbiology Reviews, 27(2) : 167-199.

Sanders, M.E., Akkermans, L.M.A., Haller, D., Hammerman, C., Heimbach, J., 2010, Safety assessment of probiotics for human use, Gut Microbes, 1(3) : 164-185.

Szajewska, H., Guarino, A., Hojsah, I., Indrio, F., 2014, Use of probiotics for management of acute gastroenteritis: a position paper by the espghan working group for probiotics and prebiotics, $J$ Pediatr Gastroenterol Nutr., 58(4) : 531-539.

Thiem, V.D., Schmidt, W-P., Suzuki, M., Tho, 1.H., Yanai, H., Ariyoshi, K., Anh, D.D., Yoshida, 1-M., 2012, Animal livestock and the risk of hospitalized diarrhoea in children under 5 years in vietnam, A European Journal Tropical Medicine \& International Health, 17(5) : 613-621.

Thomas, D.W., and Greer, F.R., 2010, Probiotics and prebiotics in pediatrics, Pediatrics, 126(6): 12171231.

Vanderhoof, J.A., Young, R., 2008, Probiotics in the united states, Clinical Infectious Diseases, 46(suppl 2) : 67-72.

Van Niel, C.W., Feudtner, C., Garrison, M.M., Christakis, D.A., 2002, Lactobacillus therapy for acute infectious diarrhea in children: a meta-analysis, Pediatrics,109(4):678-684.

Varankovich, N.V., Nickerson, M.T., and Korber, D.R., 2015, Probiotic-based strategies for therapeutic and prophylactic use against multiple gastrointestinal diseases, Frontiers in Microbiology, 6.

Wattanarat, O., Makeudom, A., Sastrauji, T., Piwat, S., Tianviwat, S., Teanpaisan, R., and Krisanaprakornkit, S., 2014, Enhacemnet of salivary human neutrophil peptide 1-3 levels by probiotic supplementation, BMC Oral Health. 